\section{JURNAL ABDIMAS

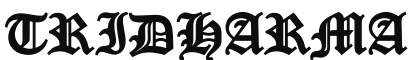

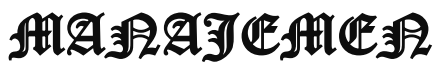

\title{
PEMANFAATAN BOTOL PLASTIK BEKAS SEBAGAI MEDIA TANAMAN SAYUR HIDROPONIK UNTUK MENINGKATKAN PRODUKTIVITAS DAN MENGHASILKAN NILAI JUAL SERTA MENAMBAH INCOME DI MASYARAKAT
}

\author{
Dinar Ambarita $^{1,}$ Mona Monica ${ }^{2}$, Annisa Mayang Arista Sembiring ${ }^{3}$, \\ Maulidya Dwi Savitri ${ }^{4}$ \\ Dosen Dan Mahasiswa Program Studi Akuntansi Universitas Pamulang \\ Dosen02308@unpam.ac.id, Monicamona872@gmail.com. \\ anisamayang11@gmail.com, maulidyasv0556@gmail.com.
}

\begin{abstract}
ABSTRAK
Seiring berjalannya waktu masalah volume sampah yang semakin meningkat perlu ditangani dengan bijak agar pencemaran lingkungan bisa dihindari, terutama sampah anorganik berupa botol plastik. Hal inilah yang mendasari kegiatan Pengabdian Mahasiswa/i Kepada Masyarakat (PmKM) yang dilakukan oleh Mahasiswa/i Universitas Pamulang mengenai Sosialisasi pemanfaatan botol plastik bekas sebagai media tanaman sayur hidroponik untuk meningkatkan produktivitas dan menghasilkan nilai jual serta menambah income masyarakat.

Pemanfaatkan botol bekas sebagai media tanaman hidroponik adalah cara yang cukup efektif untuk membangkitkan minat dan kesadaran masyarakat tentang pentingnya mengelola limbah botol plastik. Dengan pemanfaatan botol bekas tersebut nantinya selain mengurangi sampah plastik juga dapat menciptakan nilai jual, dimana tanaman yang di budidayakan melalui hidroponik botol bekas tersebut selain dapat di konsumsi sendiri juga dapat di jadikan peluang usaha yang nantinya akan menambah income di masyarakat. Budidaya tanaman sayur di era moderen ini dapat menjadi salah satu kegiatan untuk mengisi waktu luang dengan hal positif di tengah pandemic Covid-19.

Metode kegiatan yang dilakukan pada pelatihan ini menggunakan Ceramah, diskusi dan praktik langsung tentang cara budidaya hidorponik dengan botol bekas. Dari hasil kegiatan pelatihan tersebut menunjukan bahwa masyarakat mitra khususnya ibu-ibu PKK sangat antusias tentang pemanfaatan botol bekas sebagai media tanam sayuran hidroponik karna ini merupakan hal baru yang mereka temui.
\end{abstract}

Kata Kunci : hidroponik, botol plastik bekas, income

\section{PENDAHULUAN}

Ada banyak perubahan gaya hidup yang terjadi di masa pandemi Covid-19 seperti sekarang ini. Mulai dari jam kerja, aktivitas fisik, sampai pola hidup secara keseluruhan. Akhir-akhir ini banyak orang menjalani hobi sebagai salah satu bentuk koping untuk menghindari stres. Berkebun adalah salah satunya, tidak hanya menanam tanaman hias saja, hobi menanam ini juga dilakukan dalam bentuk menanam dengan pemanfaatan air contohnya sayuran hidroponik. Budidaya tanaman sayur di era modern ini dapat menjadi salah satu kegiatan untuk mengisi waktu luang dengan hal positif di tengah pandemic Covid-19. Hidroponik sendiri diambil dari bahasa Yunani yaitu Hydro yang artinya air dan ponos yang artinya daya. Sehingga ketika dua kata tersebut di satukan akan membentuk pengertian budidaya tanaman dengan memanfaatkan air tanpa 


\section{JURNAL ABDIMAS

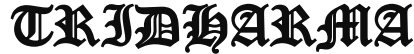

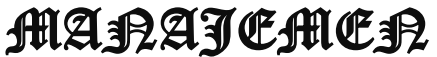

P-ISSN 2615-6849, E-ISSN 2716-070X

Jurnal ABDIMAS Vol.3,No.1,Desember 2021,Hal(92-99)

@ Prodi Manajemen Fakultas Ekonomi Universitas Pamulang

Email: abdimasjurnal.unpam@ gmail.com Telp: (021) 741-2566 menggunakan tanah menjadi media tanam (soiless) (Roidah, 2014; Syaefa et al., 2014). Teknologi pertanian hidroponik diharapkan bisa jadi alternatif untuk penduduk yang mempunyai lahan ataupun teras yang terbatas sehingga bisa dimanfaatkan selaku perihal yang berguna (Roidah, 2014).

Semakin bertambahnya manusia diiringi bersamaan dengan bertambahnya polusi dalam bentuk sampah plastik yang sangat sulit untuk di urai dan memerlukan waktu yang sangat lama. Botol plastik bekas seringkali dianggap bukan barang berguna, sebenarnya dapat dimanfaatkan menjadi berbagai macam hal salah satunya adalah untuk media tanam. Botol plastik bekas adalah salah satu jenis sampah anorganik yang banyak ditemukan di lingkungan sekitar. Sebagian besar kemasan botol plastik bekas tidak direkomendasikan untuk digunakan berulang kali, karena akan berdampak negatif bagi kesehatan meski dalam jangka waktu yang relatif lama. Akan tetapi botol plastik tersebut sebenarnya masih memilik banyak manfaat. Salah satunya yaitu dapat dijadikan sebagai media tanaman dengan sistem hidroponik. Pemanfaatan botol plastik bekas untuk media tanam juga berguna untuk mengurangi terjadinya pencemaran lingkungan yang mengurangi keindahan lingkungan itu sendiri.

Kegiatan pengabdian akan dilakukan di Balai Warga Bukit Gading Balaraja RT003/RW005 Ds. Cangkudu, Balaraja. Tujuan dari kegiatan ini yaitu 1 . memperkenalkan cara bercocok tanam tanpa lahan yang luas, 2. memberikan wawasan atau pengetahuan tentang pemanfaatan botol plastik bekas sebagai media tanam sayuran hidroponik 3. membangun dan meningkatkan kepedulian terhadap botol plastik bekas, 4. menunjukan berbagai kemungkinan usaha bercocok tanam yang sehat, bersih, aman, yang diharapkan mampu meningkatkan produktivitas, menghasilkan nilai jual serta menambah income masyarakat.

\section{METODE PELAKSANAAN KEGIATAN}

Metode yang digunakan pada pelaksanaan program pelatihan pemanfaatan botol bekas sebagai media tanaman budidaya sayur hidroponik dengan melakukan pendampingan melalui pendekatan individual dan kelompok. Pendekatan kelompok yaitu pada saat pemaparan teori tentang teknik budidaya sayur hidroponik. Dimulai dari perkenalan alat dan bahan serta tata cara penanaman sayuran. Sedangkan pendekatan individual yaitu pada saat diskusi tanya jawab dengan peserta kegiatan tentang permasalahan terutama dalam proses pelaksanaan budidaya sayur dengan teknik hidroponik menggunakan botol bekas.

Pertanyaan-pertanyaan yang diajukan oleh peserta lebih banyak ditekankan mengenai dimana tempat untuk pembelian bahan dan alat, bagaimana teknik perawatan dalam tanaman sayur hidroponik tersebut, dan manfaat yang didapatkan dari hasil pemanfataan botol plastik bekas sebagai media tanam.

Selain itu kami juga memanfaatkan Metode Demontrasi dan juga praktek, dimana para peserta bisa ikut langsung mempraktekkan tata cara budidaya tanam hidroponik menggunakan media botol bekas yang sudah disampaikan oleh pemateri.

\section{HASIL DAN PEMBAHASAN}

Kegiatan program pengabdian kepada masyarakat dengan tema "Pemanfaatan Botol Plastik Bekas Sebagai Media Tanaman Sayur Hidroponik Untuk Meningkatkan Produktivitas Dan Menghasilkan Nilai Jual Serta Menambah Income Di Masyarakat" dilaksanakan sebagai upaya memberikan wawasan atau pengetahuan tentang pemanfaatan botol plastik bekas sebagai media tanam sayuran hidroponik. Kegiatan ini juga di harapkan dapat meningkatkan produktivitas dengan bercocok tanam yang sehat, bersih dan aman yang juga dapat menghasilkan nilai jual serta menambah income masyarakat.

Kegiatan pengabdian ini fokus pada bagaimana pemanfaatan limbah botol plastik sebagai media tanam dengan sistem hidroponik. Tahap pertama kegiatan 


\section{JURNAL ABDIMAS

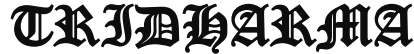 AtA}

P-ISSN 2615-6849, E-ISSN 2716-070X

Jurnal ABDIMAS Vol.3,No.1,Desember 2021,Hal(92-99)

@Prodi Manajemen Fakultas Ekonomi Universitas Pamulang

Email: abdimasjurnal.unpam@ gmail.com Telp: (021) 741-2566 pengabdian, tim memberikan masker bagi masyarakat yang tidak menggunakan masker saat datang ke balai desa serta memberikan hand sanitizer untuk tetap menjaga protokol kesehatan. Tim memberikan pemaparan tentang tanaman sayur hidroponik serta botol plastik bekas yang dapat dijadikan wadah menaman tanaman tersebut.

Selanjutnya memperkenalkan alat dan bahan yang diperlukan pada proses budidaya tanaman dengan sistem hidroponik. Alat dan bahan yang digunakan antara lain adalah rock wool sebagai media penyemaian benih sayur, benih yang digunakan adalah kangkung, salada, dan pakcoy. Kain flanel sebagai perantara penyaluran nutrisi $\mathrm{AB}$ mix ke tanaman. Nutrisi AB mix khusus untuk tanaman sayur. Botol plastik bekas sebagai media tanaman. Nampan untuk penyemaian benih serta beberapa alat pendukung lainnya. Sembari memperkenalkan alat dan bahan tersebut, mahasiswa juga langsung mendemonstrasikan tata cara bercocok tanam hidroponik tersebut dengan sesekali di isi dengan sesi tanya jawab antar peserta.

Setelah paham tentang cara bercocok tanam secara hidroponik, peserta langsung mempraktekkan cara bercocok tanam menggunakan metode hidroponik dengan memanfaatkan limbah botol plastik. Peserta dibimbing dengan beberapa mahasiswa untuk langkah langkah pembuatannya. Setelah kegiatan pelatihan pembuatan hidroponik yang dimulai dengan sosialisasi pemaparan dan teori tentang hidroponik, kemudian dilakukan pelatihan langsung yaitu cara penyemaian bibit sayuran serta cara membuat wadah hidroponik dari botol air mineral bekas. Ibu-ibu PKK mengikuti program dengan antuisias karena melalui program pelatihan dan sosialisasi ini Ibu-ibu PKK dilatih untuk bisa berpikir kreatif, mandiri dan peduli lingkungan. Dengan pemanfaatan botol plastik bekas yang merupakan salah satu solusi mengurangi kerusakan lingkungan. Selain itu, budidaya sayuran hidroponik di lingkungan rumah dapat menjadi salah satu kegiatan yang bermanfaat di masa pandemi covid-19 dengan hasil budidaya yang dapat dikonsumsi sendiri juga bisa menambah income bagi warga sekitar.

\section{KESIMPULAN}

Adapun kesimpulan yang kami dapat dari kegiatan PKM adalah bahwa dengan metode yang digunakan pada kegiatan ini telah mampu meningkatkan pengetahuan mitra yaitu ibu-ibu anggota PKK di Bukit Gading Balaraja RT003/RW005 Ds. Cangkudu, Balaraja terkait pengetahuan tentang cara pemanfaatan botol plastik bekas sebagai media tanaman sayuran hidroponik, membangun dan meningkatkan kepedulian terhadap botol plastik bekas,menunjukan berbagai kemungkinan usaha bercocok tanam yang sehat, bersih, aman, yang diharapkan mampu meningkatkan produktivitas, menghasilkan nilai jual serta menambah income masyarakat.

\section{Gambar 1. Peserta datang ke balai warga untuk acara PKM serta pemberian masker dan hand sanitizer untuk tetap menerapkan protokol kesehatan.}

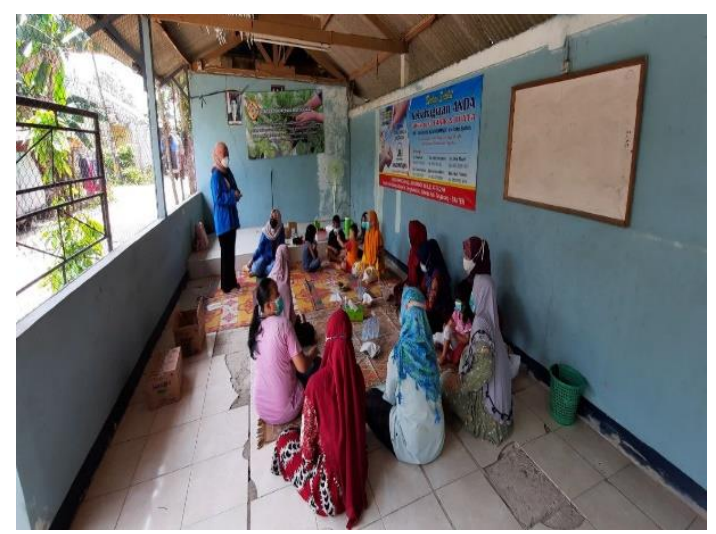

(Sumber : Dokumentasi pribadi)

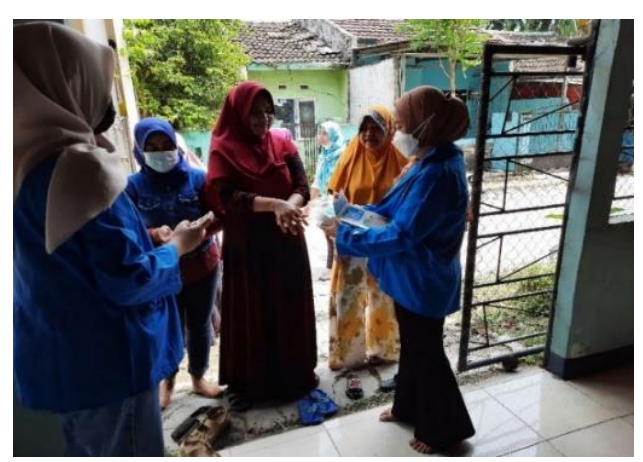




\section{JURNAL ABDIMAS

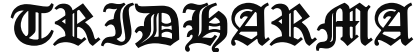 AHA}

P-ISSN 2615-6849, E-ISSN 2716-070X

Jurnal ABDIMAS Vol.3,No.1,Desember 2021,Hal(92-99)

@Prodi Manajemen Fakultas Ekonomi Universitas Pamulang

Email: abdimasjurnal.unpam@ gmail.com Telp: (021) 741-2566
Gambar 2. Sesi ceramah pemaparan teori, demonstrasi tata cara penanaman sayuran hidroponik ke botol plastik bekas dan sesi tanya jawab.

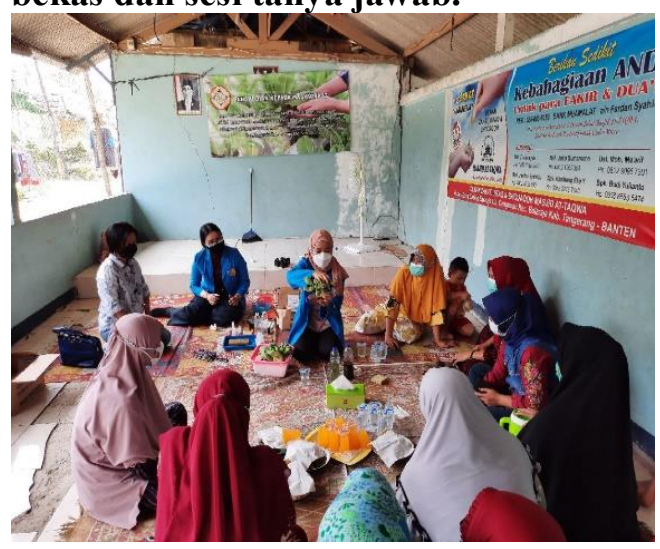

(Sumber : Dokumentasi pribadi)

\section{DAFTAR PUSTAKA}

Fakhrul Irfan Khalil, Sirajuddih Haji Abdullah, Joko Sumarsono, Asih Priyati, Diah Ajeng Setiawati. 2021. Pemanfaatan Limbah Botol Plastik Sebagai Media Hidroponik Di Desa Kediri Kecamatan Kediri Kabupaten Lombok Barat. Jurnal Abdi Mas TPB. 3(1), 40 - 48. ISSN 2655-7533

Pasaribu, V. L. D., Agrasadya, A., Shabrina, N., \& Krisnaldy, K. (2020). Menjadi Enterpreneur Muda Yang Memiliki Jiwa Leadership Untuk Menghadapi Masa Depan. Abdi Laksana: Jurnal Pengabdian Kepada Masyarakat, 1(1).

Pasaribu, V. L. D., Susanti, F., \& Hartuti, E. T. K. (2019). Memotivasi Siswa dan Siswi SMK Letris Indonesia di Dalam Menentukan Pilihan Untuk Melanjutkan Pendidikan Atau Bekerja Setelah Lulus Sekolah. Jurnal Pengabdian Dharma Laksana, 1(2), 161-172.

Pasaribu, V. L. D., Sulaiman, S., Sutiman,
S., Thaharudin, T., \& Purnomo, B. Y. (2020). Pengenalan Letak Posyandu Terdekat Dikelurahan Pisangan Dengan Manajemen Pemasaran Revolusi 4.0 Untuk Meningkatkan Pengetahuan Masyarakat Letak Dan Fungsi Posyandu Terdekat Pada Kelurahan Pisangan. Dedikasi Pkm, l(1), 105110.

Pasaribu, V. L. D., Oktrima, B., Prabowo, B., Arianto, N., \& Haryoko, U. B. (2020). Progam Pendampingan Dan Penyelenggaraan Pendidikan Anak Pada Usia Dini Terhadap Prestasi Belajar Dilingkungan Rt $020 \mathrm{Rw}$ 009. Kel Giri Peni. Kec Wates. Yogyakarta. Jurnal Lokabmas Kreatif, 1(1), 71-75.

Pasaribu, V. L. D., Jannah, M., Fazar, M., Putra, S. P., Monalisa, M., \& Sofa, M. (2021). MENINGKATKAN PRODUKTIVITAS USAHA DIMASA PANDEMI PADA IBU PKK RT 004/003 KELURAHAN SAWAH BARU CIPUTAT, TANGERANG SELATAN. Abdi Laksana: Jurnal Pengabdian Kepada Masyarakat,2(2), 295301.

Pasaribu, V. L. D., Yuniati, H. L., Pranata, R., Sembayu, R., Purba, S. M., \& Nurbayani, T. T. A. (2021). MANAJEMEN KEUANGAN UNTUK MENGHADAPI DAN BERTAHAN DI ERA COVID 19. Jurnal Abdimas Tri Dharma Manajemen, 2(2), 12-18.

Pasaribu, V. L. D., Dwiyatni, A., Sabina, C., Ridwan, M., Gunawan, D. D., \& Noviani, B. C. (2021). EVALUASI PENERAPAN 3M DIMASA PANDEMIC COVID 19. Jurnal Abdimas Tri Dharma Manajemen, 2(2), 54-60.

Pasaribu, V. L. D., Syafei, A. N., Farhan, A., Aufaizah, A., Irani, C., \& 


\section{JURNAL ABDIMAS

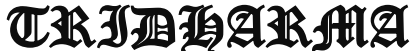

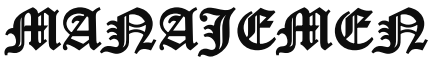

P-ISSN 2615-6849, E-ISSN 2716-070X

Jurnal ABDIMAS Vol.3,No.1,Desember 2021,Hal(92-99)

@ Prodi Manajemen Fakultas Ekonomi Universitas Pamulang

Email: abdimasjurnal.unpam@ gmail.com Telp: (021) 741-2566
Firtiayani, S. R. (2021). PENGARUH DISPLIN

PROTOKOL KESEHATAN TERHADAP PENCEGAHAN PENULARAN VIRUS COVID19. Jurnal Abdimas Tri Dharma Manajemen, 2(2), 91-98.

Pasaribu, V. L. D., Septiani, F., Rahayu, S., Lismiatun, L., Arief, M., Juanda, A., ... \& Rahim, R. (2021). Forecast Analysis of Gross Regional Domestic Product based on the Linear Regression Algorithm Technique.

Priadi, A., Pasaribu, V. L. D., Virby, S., Sairin, S., \& Wardani, W. G. (2020). Penguatan Ekonomi Kreatif Berbasis Sumber Daya Desa Dikelurahan Rempoa. Abdi Laksana: Jurnal Pengabdian Kepada Masyarakat, 1(3), 356-35

Pasaribu, V. L. D., Priadi, A., Anismadiyah, V., Rahayu, S., \& Maduningtias, L. (2021). PENYULUHAN KREATIF DAN INOVATIF MENINGKATKAN MUTU PRODUKSI UMKM DI DESA BELEGA KABUPATEN GIANYAR. Pro Bono Jurnal Pengabdian Kepada Masyarakat, 1(02).

Pasaribu, V. L. D. (2021). PELATIHAN BERBASIS ONLINE DI ERA COVID-19. Jurnal Abdimas Tri Dharma Manajemen, 2(3), 26-32.
Pasaribu, V. L. D., \& Setyowati, R. (2021). ADAPTASI KEHIDUPAN NEW NORMAL PADA MASA PANDEMI COVID-19 DIYAYASAN PONDOK PESANTREN DAN PANTI ASUHAN NURUL IKHSAN KECAMATAN SETU, KOTA TANGERANG SELATAN. Jurnal Lokabmas Kreatif: Loyalitas Kreatifitas Abdi Masyarakat Kreatif, 2(2), 82-88.

Ryani Dhyan Parashakti, Didin Hikmah Perkasa, Nur Endah Retno Wuryandari. Pemberdayaan Masyarakat Melalui Penyuluhan Hidroponik Bagi Masyarakat Tanjung Duren Utara Jakarta Barat. 2021. KOMMAS: Jurnal Pengabdian Kepada Masyarakat Universitas Pamulang. 2(2). ISSN: 2721-0235

Sukron Romadhona, Joko Sudibya, T. Sutikto, Laily Mutmainnah, Arizona Rambi. 2019. Pemanfaatan Limbah Gelas dan Botol Plastik Sebagai Media Tanam Penunjang Peningkatan Pendapatan Masyarakat Melalui Pembentukan Kampung Hidroponik di Lahan Rawa. Warta Pengabdian, University of Jember. 33(4), 147156. 